\title{
Planting coconuts in Indian villages: ethnoecological aspects and evaluation of a "sustainable development" project
}

\author{
Rodolfo Salm ${ }^{1,5}$, Lisa Feder ${ }^{2}$,Euphly Jalles-Filho ${ }^{3}$ \& Mario Augusto Gonçalves Jardim ${ }^{4}$ \\ ${ }^{1}$ Faculdade de Biologia, Universidade Federal do Pará - UFPA, \\ Rua José Porfírio, 2515, CEP 68372-040 Bairro de São Sebastião, Altamira, PA, Brazil \\ ${ }^{2}$ International Rivers, 5362 Manila Avenue, Oakland, Ca 94618, USA, e-mail: lkfeder@gmail.com \\ ${ }^{3}$ Instituto de Neuropsicologia e Biofeedback - INBIO, \\ Rua Thomaz, Nogueira Gaia, 83, CEP 14020-290 Ribeirão Preto, SP, Brazil, e-mail: ejalles@inbio.com.br \\ ${ }^{4}$ Museu Paraense Emílio Goeldi, Coordenação de Botânica, \\ Av. Magalhães Barata, 376, CEP 66040170 Nazaré, Belém, PA , Brazil, e-mail: jardim@museu-goeldi.br \\ ${ }^{5}$ Corresponding author: Rodolfo Salm, e-mail: rodolfosalm@ufpa.br
}

SALM, R., FEDER, L., JALLES-FILHO, E. \& JARDIM, M.A.G. Planting coconuts in Indian villages: ethnoecological aspects and evaluation of a "sustainable development" project. Biota Neotrop. 10(1): http:// www.biotaneotropica.org.br/v10n1/en/abstract?article+bn02210012010.

\begin{abstract}
Although scientists and policy makers embrace the general concept "sustainable development", there are few who agree on how to carry out sustainable development in specific situations. As such, sustainable development projects among ethnoscientists are widely critiqued as to how well they are inter-culturally formulated. Here we report on a controversial case of planting coconuts in Kayapó Indian villages of southern Pará, Brazil and offer our own self-critique. We began under the premise that reforestation and Kayapó general health/nutrition go hand in hand. Therefore, the flourishing of coconut culture will contribute to forest conservation in the long run, in itself, and simultaneously, maintain good nutrition for the Kayapó people who protect the forest from the threat of non-sustainable practices. We take an ethnoecological approach in discovering how Kayapó behavior affects the growth and flourishing of coconut culture when fostered with external supply. We present the results of two field trips to the Kayapó indigenous territory, where we found socio-ecological factors relevant to the success of our project supporting the culture of coconuts in indigenous villages. First, in November 2007, we visited Kikretum, Moikarakô and Aukre villages (among 10 villages which received coconut seedlings from our support program) to deliver a second shipment of coconut seedlings (the first shipment to these villages took place in April 2006) and quantitatively described one aspect of coconut seed-disperser's (the Kayapó's) behavior. We looked specifically at how the pre-existing coconuts palms were distributed among the Indian families, how they distributed last year's shipment, and how that shipment survived due to ethnoecological factors. Second, in July 2008 we visited Kokraimoro and Pykararankre villages and estimated the position of the previously existing and newly planted coconut palms in relation to other cultivated trees by making use of censuses departing from the village center to their outside limits. In the three Indian villages we visited in 2007 , virtually all pre-existing coconut trees belonged to a select few families, and the coconut fruit distribution was, in most cases, highly concentrated among these family members. However, assuming that all the coconut saplings that survived the first year will reach maturity (from the first shipment in April 2006), they represent a remarkable increase in the projected number of adult coconut palms in the three visited villages (48, 195 and $101 \%$ in Kikretum, Moikarakô and Aukre, respectively), and a substantial reduction in the inequality in access to coconuts. In the 2008 field trip, we found that the Indians usually plant coconuts very close to their houses where competition with other cultivated trees may hinder the palms development.
\end{abstract}

Keywords: coconuts, deforestation, economy, indians, palm, seed dispersal, Tropical Forest.

SALM, R., FEDER, L., JALLES-FILHO, E. \& JARDIM, M.A.G. Aspectos etno-ecológicos do plantio de cocoda-Bahia em aldeias Kayapó do sudeste da Amazônia. Biota Neotrop. 10(1): http://www.biotaneotropica.org. br/v10n1/en/abstract?article+bn02210012010.

Resumo: Apesar de cientistas e tomadores de decisão abraçarem o conceito geral de "desenvolvimento sustentável", há pouco acordo sobre como se atingir esta meta em situações específicas. Assim, projetos de desenvolvimento sustentável são amplamente criticados por etno-cientistas quanto à forma como são inter-culturalmente formulados. Aqui reportamos um caso controverso de plantio de coco-da-Bahia em aldeias Kayapó do sul do Pará, e fazemos a nossa autocrítica. Nós partimos da premissa de que o reflorestamento e o estado geral de saúde/nutrição caminham lado a lado. Portanto, o desenvolvimento da cultura de cocos por si só deve contribuir para a conservação da floresta no longo prazo e, simultaneamente, contribuir para o bom estado nutricional do povo Kayapó que protege a floresta da ameaça de práticas não-sustentáveis. Nós buscamos descobrir como que o comportamento dos Kayapó afeta o desenvolvimento da cultura de cocos quando amparada com suporte externo. Nós apresentamos resultados de duas viagens de campo para a terra Kayapó, onde detectamos fatores sócio-ecológicos relevantes para o sucesso 
de nosso projeto de apoio à cultura de coqueiros nas aldeias indígenas. Primeiro, em novembro de 2007, nós visitamos as aldeias Kikretum, Moikarakô e Aukre (dentre 10 aldeias que receberam mudas de coqueiros de nosso programa de apoio) para entregar um segundo carregamento de mudas de coqueiro (o primeiro carregamento aconteceu em abril de 2006). E descrevemos quantitativamente um aspecto do comportamento dos dispersores de sementes de coco (os Kayapó). Especificamente, como as palmeiras pré-existentes nas aldeias são distribuídas dentre as famílias dos índios e como este carregamento sobreviveu a fatores etno-ecológicos. Segundo, em julho de 2008 nós visitamos as aldeias Kokraimoro e Pykararankre e estimamos a posição dos coqueiros pré-existentes e dos novos em relação a outras árvores cultivadas, fazendo uso de censos partindo do centro das aldeias para seus limites exteriores. Nas três aldeias indígenas visitadas em 2007, virtualmente todos os coqueiros pré-existentes pertenciam a poucas famílias e a distribuição de frutos era, na maior parte dos casos, altamente concentrada dentre os membros destas famílias. Entretanto, assumindo que todos os coqueiros jovens que sobreviveram ao primeiro ano chegarão à maturidade (do primeiro carregamento em abril de 2006), eles representam um aumento considerável no numero projetado de coqueiros adultos nas três aldeias visitadas (48, 195 e 101\% em Kikretum, Moikarakô e Aukre, respectivamente). E uma redução substancial na desigualdade de acesso aos cocos. Na expedição de 2008, encontramos que os índios geralmente plantam coqueiros bem próximos das suas casas onde a competição com outras árvores cultivadas podem limitar o desenvolvimento das palmeiras.

Palavras-chave: coqueiros, desmatamento, economia, índios, palmeiras, dispersão de sementes, Floresta Tropical.

\section{Introduction}

A major limitation of the concept of sustainable development is that it defines goals broadly but cannot dictate how to meet these goals in specific social, ecological, economic, cultural or historical situations (Rist \& Dahdouh-Guebas 2006). This becomes increasingly complicated when concrete issues of development are at stake (Kellert 1997). In line with previous theories on appropriate methodologies for carrying out sustainable development, we take an ethnoscientific approach to our study, combining aspects of anthropology with tropical ecology (Redclift \& Benton 1994). We offer self-critique in the discussion, defending our current position while acknowledging room for improvement toward greater local participation in the future of the project.

Here we report on a controversial case of planting coconut palms in Kayapó Indian villages of southern Pará, as a strategy for forest conservation and food security. It is controversial because, coconuts are an exotic species, despite the fact that they have been widely planted and used as a food source throughout the tropics. Exotic plants have inherited a poor reputation in the protection of biodiversity due to many cases of invasive species that have caused ecosystem degradation by becoming pests in ecosystems where they did not co-evolve. However, such hazards are limited to plant species characterized by a strong capacity for rapid growth and dispersal (Mills et al. 1993, Case 1996, Myers et al. 2000). Unintentional or inadvertent spread of valuable tree species as a side-effect of certain patterns and practices and the fortuitous spread of valuable trees can and does occur over large areas as a result of the interaction between land use and ecological process (Unruh 1994). Nevertheless, due to characteristics of coconut biology, the establishment of coconuts in the villages cannot be a by-product of the functioning of the land-use ecology itself. Coconut palms (Cocos nucifera), despite being an exotic species in Brazil, do not become invasive due to the large size of the seed and the difficulty in reproduction without human interference.

We advocate that the expansion of coconut (Cocos nucifera) palms in indigenous areas in the Amazon could be an important step for biodiversity conservation. It would contribute to nutrition and hydration for the indigenous people who defend the land from nonsustainable developers during these years where they are experiencing a population expansion that weighs on their natural resources (Salm et al. 2007). We consider the potential that increased production of this species could help to mitigate the negative impact of rapid hu- man population growth in these areas by simultaneously increasing (coconut) tree populations and improving the indigenous nutrition.

Dahdouh-Guebas et al. (2003) define a typology of scientific approaches to local knowledge including utilitarian, paternalistic, neocolonial, essentialist and intercultural types in which "intercultural" is the most equal relationship between local and outsider. We support an intercultural methodology in theory, however, we recognize that there are shortcomings in reaching this ideal in a real situation. While we aim to work in an intercultural basis, in practice, due to scarcity of founds and precarious communication means with the Indian villages, we assume aspects of paternalism, essentialism and a lack of acknowledgement of the local viewpoint. We hope to remedy this situation as our experience grows. We assumed a predominantly paternalistic attitude according to the categories as specified in Rist and Dahdouh-Guebas, in delivering coconut saplings and conducting research largely without the input of the Kayapo people (see Rist \& Dahdouh-Guebas 2006, p. 474).

We investigated elsewhere the actual economic relevance of coconuts for the Kayapó by comparing age/size pyramids of human and coconut populations. We found that, presently, this exotic palm is not important for the subsistence of these Indians, due to coconut scarcity and traditional food pattern, and such importance is not foreseeable without external support (Salm et al. 2007). Based on our observations we believe that the scarcity of coconut palm has been a point of differentiation in social status for the families that have them, not for the economic opportunity that comes from selling the fruits on the market (the Kayapó do not sell these fruits, and won't be able to do so in the foreseeable future, due to their geographic isolation) but because of the increased social status for families that have access to a more rare food*. This is quite unlike mangos, a non-native species, that grow with such abundance since their importation, that they are considered common property of the village.

\section{Background on Kayapó villages}

The term Kayapó, used to include various separate but closely related subgroups of the Jê family speaking group (Léa 1992), is a term of another indigenous language introduced by the Portuguese.

\footnotetext{
* The Kayapó situation is unlike the Kuna of Panamá who sell these fruits to Colombians, and whose fortunes vary according to how assiduously their ancestors planted coconuts (Howe 2002).
} 
The Kayapó call themselves Mebengôkrê ("people of the space between the waters") (Posey 1989). The Kayapó social organization is based on nuclear families and extended family households. There is a well-defined sexual division of labor. Mans are mainly responsible for opening gardens, hunting and fishing, and women are responsible for planting and maintenance of the agricultural plots (Turner 1995). The matri-uxorilocal extended family is a basic economic unit: women generally reside in the same house of their childhood, and young men move into the household of their wife's and her parents. Thus, the wife's parents have strong influence on their daughter's husband and the young family, giving maternal parents access to a share of the production of the daughter's family (Turner 1995). There is historical evidence that in the past the Kayapó lived in larger villages, with a complex age-grade and lineage organization (Posey 1994). Today, the Kayapó village houses are traditionally disposed around an open circle, or plaza, around the warrior-house (called "ngobe"), a sort of parliament at the center of the village (Figure 1). The "property" of space at the Kayapó villages is roughly divided in slices that depart from the center of the plaza, pass through the houses and extend towards the surrounding forest. As such "slices" go further beyond the village houses, they progressively lose meaning until a point when the territory is considered public. In the scheme of the hypothetic village of Figure 1, for example, the members of the family from the house 3, or their ancestors, planted a larger area of fruiting trees behind their houses than compared to house 4. Thus, house 3's territory extends further.

Furthermore, families have individual plots or crop-fields that are located 1-3 km outside of the village, and planted through a slash and burn method. Common species include bananas and manihot. Groups of families share responsibilities for gardens of sweet potatoes and other things.

The Kayapó horticulture was traditionally a complex system, including a diversity of agricultural combinations such as house gardens, forest fields and agricultural plots on hills, among other things, due to the necessity of providing food for trekking. Nowadays, with the decrease of trekking, the maintenance of travel or mobile gardens is less common (Hecht \& Posey 1989, Posey 1985). Today, preparing a plot starts with the felling of big trees by men, while some women help either with cutting smaller branches or giving support by preparing food or bringing drinking water. Village plots are generally burned pending a decision based on weather conditions and other practical or cultural elements (Morsello 2002). Mulching is done by adding

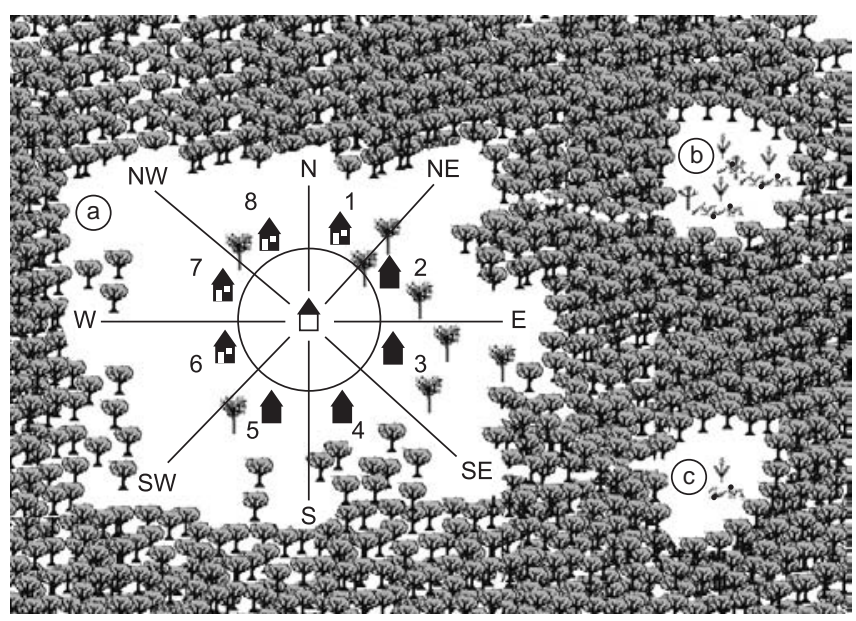

Figure 1. Schematic representation of a) an ideal Kayapó village with 8 houses, and b-c) two crop fields associated. See the text for further information. certain plant parts, as well as applying ashes, termite nests or bones, especially below long-lived species (Hecht \& Posey 1989).

Of the three villages in which we worked in 2007, Kikretum village is the largest, and closest village to a Brazilian town (Figure 2). The residents have access to electricity and telephone in some areas, and travel easily to the Brazilian town for resources. Some residents have brought in and planted coconut seeds on their own accord. Aukre and Moikarakô villages are situated farther from the cities and have difficult access to Brazilian cities. They have enjoyed rainforest harvest projects in years past and a fair amount of contact with researchers. Moikarakô is the newest and most remote of the three villages we visited in November 2007, since it was built in 2001, after the former Moikarakô village some kilometers away accidentally burned down. It is unique in that this village has the largest number of adult coconuts, due to a previous provision of dwarf coconut seedlings by Brazilian Indian National Fundation (FUNAI, Fundação Nacional do Índio), totally independent of our coconut project, to supply this new village with a gift of food sources. Such action also resulted in the most equal distribution of coconuts to households per three villages (for a detailed description of these villages see Salm et al. 2007).

Pykararankre village is situated on the right margin of the Xingu River, while Kokraimoro, a few kilometers from the northern border of the Kayapó lands along the Xingu River, is on the left bank. Kokraimoro is an older village. It was created in the 1950's and currently has a total population of around 400 people living in 32 households. Thirty kilometers upstream, Pykararankre is relatively new; it split from Kokraimoro in the 1997-1998 period and has approximately 200 people living in 22 households.

\section{Indigenous role in conservation}

Indigenous peoples have been generally living in a sustainable manner in the Amazon for centuries. Today, we count on them to do so. Remaining regions of preserved forests around the world often overlap with areas used and claimed by indigenous communities (Redford \& Stearman 1993). The worldwide importance of indigenous people for conservation is highlighted by the sizable area that they control, and it is argued that their traditional livelihoods often

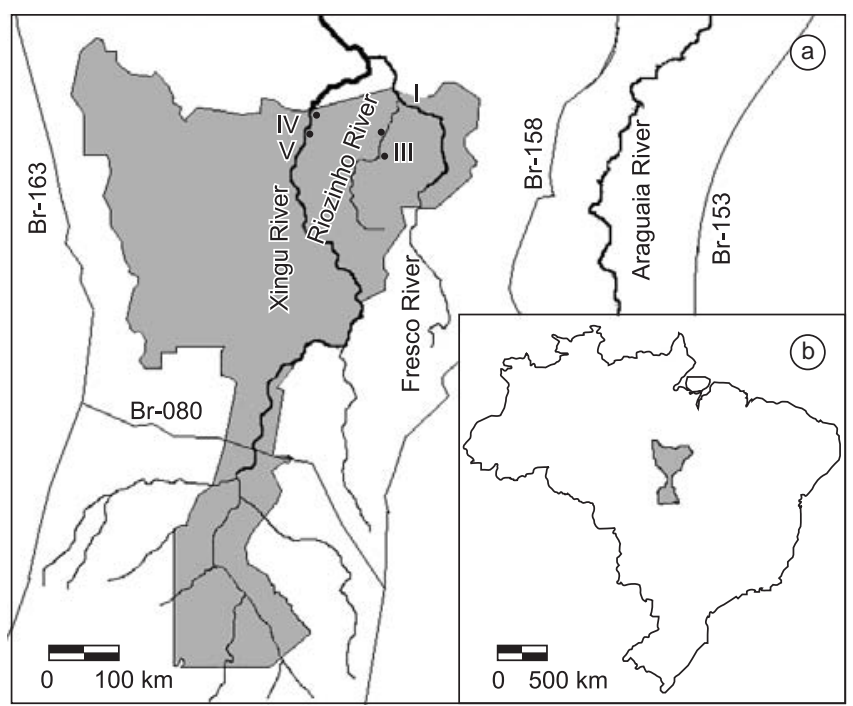

Figure 2. a) The $14,197,666$ ha block of indigenous lands (in grey), composed by the Kayapó and the contiguous Badjonkore, Baú, Capoto/Jarina, Menkragnoti, Paraná, Batovi, Wawi and Parque do Xingu. Roman numbers indicate the position of (I) Kikretum, (II) Moikarakô, (III) Aukre, (IV) Kokraimoro and (V) Pukakarankre villages; lines represent either roads or rivers. b) The block of indigenous lands in relation to the map of Brazil. 
produce little or insignificant environmental impacts (Posey 1983, Anderson \& Posey 1989a, Alcorn 1995). Several studies have shown high levels of biological diversity in indigenous areas and little impact on the environment produced by subsistence livelihoods (Anderson \& Posey 1989b, Posey 1983).

However, over the past thirty years, some scholars and environmentalists have come to believe that indigenous sustainable lifestyle in the rain forest is not necessarily a conscious choice or an intrinsic characteristic of indigenous people; rather, sustainability has been a matter of circumstance: a small population, a large land mass, and a lifestyle that utilizes only renewable forest products (Redford \& Stearman 1993, Redford \& Sanderson 2000). As a matter of fact, all too frequently, indigenous people have proven their ability to practice environmentally destructive acts such as overhunting to maintain their diet, and to make concessions to loggers and miners in exchange for money and material goods (Schwartzman et al. 2000, Zimmerman et al. 2001, Peres \& Zimmerman 2001). Indigenous peoples systems can indeed cause extinction of some local populations of plants and animals, especially large mammals (Redford \& Sanderson 2000, Terborgh 2000). In defense of the Indians, one could say that these impacts are also results of external disturbance. For one, a sedentarity lifestyle has been imposed by the Brazilian government, causing overhunting and gathering in the vicinity surrounding the villages. Also, environmental hazards from non-indigenous practices such as gold mining in the region have caused a negative environmental impact (Turner 1992).

The Kayapó indigenous group inhabits a 13 million ha government-delineated land reserve across Pará and Mato Grosso in the Xingu River Basin in almost pristine condition (Turner 1995). This area is particularly important for biodiversity conservation in eastern Amazonia because the low ratio of people to hectares allows the Indians to maintain the integrity of the ecosystems. This area, greater than the size of New York State, effectively protects seasonally-dry Amazonian forests by containing the spread of the chief environmental threats to the region, such as the construction of paved roads and hydroelectric dams, and the clearing of forests for pastures and soybean plantations (Zimmerman et al. 2001).

The Kayapó indigenous land was in the centre of the hot debate of environmentalists, explained above, in the journal Conservation Biology in June 2001, about the circumstantial or intrinsic nature of the importance of traditional peoples for conservation. Their huge area, and the remarkably well-preserved status of these lands compared to the adjoining areas was cited by Schwartzman et al. (2001) in a controversial paper that calls us to "rethink" tropical forest conservation. The example urges that forest residents are "potent political actors," essential for long-term conservation, and that underestimating their importance would be a mistake with regard to the broader objectives of conservation. These authors argued that, given adequate territory indigenous people do not threaten game species. They cite the Kayapó lands as an example where, according to Peres (2000), in the proximities of a Kayapó village (Aukre) the game biomass per square kilometre is higher than at a number of unhunted sites elsewhere, and observed that the area not actively hunted in the Kayapó reserve has an enormous game biomass per square kilometer. However, Peres and Zimmerman (2001) recall that there are significant density differentials between hunted and unhunted areas for most game species in the Kayapó reserve (Nascimento 1999, Peres 2000) and observe that a key conservation point to occupation of forests by indigenous communities is that they have no cultural experience with and little present capacity to engage in large-scale agriculture in check with limited population growth.

The Kayapó were once semi-nomadic and their mobile lifestyle afforded them a continual diverse supply of food (Vidal 1977). They were possibly pushed away by the Portuguese from their savannah lands of central Brazil into this condition in which agriculture was not important. They moved through the forest, hunting and gathering as they went, and planting crops for the future when they returned. Trekking was more usual and lasted longer, sometimes of years (Posey 1981). But the missionaries and the Brazilian government, then represented by the SPI (Service of Indian Protection), induced them to settle into permanent villages, mostly in the 1970's (Turner 1992). Permanent settlement coupled with their growing population is causing a scarcity in edible forest products and in fish in the vicinities surrounding their villages. Over the last two decades, the Kayapó experienced a demographic explosion. Within certain groups, the annual population growth rates reached $5 \%$. In some villages the population doubles every fourteen years (Verswijver 1992). For the Kayapó of south-eastern Amazonia, the demographic explosion, coupled with their increasing dependence on money to purchase industrialized goods substantially increases the pressure on their lands.

Today, in many villages, the Kayapó travel farther and farther from their homes to find the abundant food sources of the days past since they settled in permanent villages. They also cultivate fruit trees close to their homes so that they need not travel as far (see results). If neither are done adequately, as it is proving to be the case, the negative impact that the Indians have upon their land immediately surrounding the villages, although small at the landscape level, will likely grow and their nutritional problems will also increase. However, we recognize that increased population can also increase the Kayapó capacity to defend their land from invasion by non-sustainable developers. Therefore, with the aim of securing biological conservation in Eastern Amazonia, it would be wise to take new measures to ensure ongoing sustainability of the forest and the Kayapó population, simultaneously; thus the coconut planting project. While the idea from the project did not come uniquely from us (the scientists), it was primarily our initiative that brought this project to fruition.

\section{Coconut ecology and evolution}

Coconuts belong to the particular group of plants whose seeds are predated and dispersed by the same animals: humans. Another example of such relationship is represented by agoutis and many New World large-seeded plants (Smythe 1978, Dubost 1988). Also particular to coconuts are their extremely large seeds and among plants there is a general negative relationship between seed size and probability of seed dispersal (Howe 1982, Westoby et al. 1996). Coconut evolution was marked, in its early times, by the possibility of seed dispersal by travel in the sea between the highly disturbed small islands of the Pacific Ocean of Southeastern Asia, which favored the development of large husked-fruits with high flotation capacity. It is likely that, since the first moment when the humans arrived to these islands, tens of thousands of years ago, they considered the palm species useful and began to symbiotically consume and disperse selected varieties of fruits. Such islands were distinguished by the absence of land-based natural resources and the peoples that domesticated it used all parts of coconut trees in their daily lives (Harries 1979).

A dramatic change in the history of the still ever-growing distribution of this palm happened with the European marine expansion, when the worldwide traveling ships took the species to virtually all coastal areas in the tropical region. The European travelers of the XVI Century were amused by the uses of coconuts in Eastern India and promoted the great expansion of this species to its current pantropical distribution by taking fruits for oceanic journeys for food and drink. From the coasts, coconuts are also dispersed, always by humans, to the interior of continents (Harries 1979). Today, coconuts are an important source of raw material in nearly one hundred coun- 
tries around the tropics and are used in the production of dozens of products (Cuenca 1997).

Despite being an exotic species in Brazil, coconuts were rapidly spread over the Atlantic coast and coconut fruits are part of the Brazilian cuisine both in the form of dry-coconut and coconut milk, a generic term for the highly nutritious aqueous extract of the solid coconut endosperm (Okwu 2001, Seow \& Gwee 1997). The culture of coconuts has been substantially expanding in Brazil due to the domestic demand for coconut water, widely consumed in Brazilian cities.

In this paper we use an ethnoecological method to qualitatively and quantitatively describe one aspect of coconut seed-disperser's (the Kayapó's) behavior, which we considered relevant for success of the program: specifically, how the existing coconuts palms prior to our first and second shipments were distributed among indigenous families an how this affected coconut growth. We also discuss how Kayapó behavior as seed dispersers might change with continued shipments of coconut saplings, and thereby, affect the growth and flourishing of coconut trees in the future, toward the end of making coconuts an important component to the nourishment for the Kayapó population.

\section{Methods}

In a meeting between FUNAI (the Brazilian Indian National Foundation) and the Kayapó in the Kayapó village of Aukre, in October 2005, Kayapó Indians requested support to increase the culture of coconuts (Cocos nucifera) in their lands (Salm et al. 2007). We believe that increasing coconut trees in the vicinity surrounding the villages, the Kayapó would increase the consumption of these fruits, which, when available, they have proven to enjoy a lot.

The beginning of the rainy season, which starts in October and lasts until April is the most appropriate time for planting the coconut seedlings, since it allows for a longer period for the development of their root system before the dry-period, which is particularly severe in that area with up to three months of virtually no rain at all. Unfortunately, due to bureaucratic reasons, it was not before April 2006, that, with the support of FUNAI, we brought a total of 1,800 coconut seedlings of the dwarf variety selected by the Brazilian Agricultural Research Corporation (EMBRAPA, Empresa Brasileira de Pesquisa Agropecuária), in Aracajú, state of Sergipe, in the Northeastern coast of Brazil, to the Kayapó villages of Kikretum, Moikarakô and Aukre (600 seedlings for each village). Further details about such expedition were described elsewhere (Salm et al. 2007).

In the 2005/2006 period, our team worked on the political maneuvers to make the funding of the first expedition possible, as the rainy season progressed. Our concerns about planting the seedlings in time to receive the maximum benefits from the rains grew. In light of the actual time of planting, the commencement of the dry season, the FUNAI staff raised concern about the most appropriate way to distribute the coconut seedlings to the Kayapó to ensure optimal chances of being properly watered in the first dry-season. The FUNAI agents affirmed that the seedlings should not be treated as common property or in other words, the responsibility of each village as a whole. Instead, they should be distributed family by family.

With the aim of conducting an investigation on FUNAI's suggested methodology for seed distribution, we decided to give, in the 2006 season, an identical number of coconut seedling (600) to the three villages and to divide such seedlings into two groups, one that would be common property to all village members and another that would be divided equally among the village families. Every family in Kikretum, Moikarakô and Aukre received 5, 10 and 7 seedlings each, respectively, and the remaining seedlings were given to the villages as common property. With more time for planning, in November 2007, the commencement of the rainy season, and with the support of the Brazilian National Health Foundation (FUNASA, Fundação Nacional de Saúde), and the non-governmental organization (NGO), Protected Forest Association (AFP, Associação Floresta Protegida), we distributed an additional 5,000 coconut saplings to approximately 5,000 Indians in 10 Kayapó villages in protected indigenous territory in southern Pará and northern Mato Grosso (Table 1). Our team consisting of a tropical biologist, Dr. Rodolfo Salm, and a cultural anthropologist, Dr. Lisa Feder, and our Brazilian and Kayapó assistants, personally delivered the coconut seedlings to the families in the villages, Kikretum, Moikarakô and Aukre.

\section{Coconut distribution among the Kayapó families}

In November 2007, we personally delivered 2700 coconut saplings to the three villages. The seedlings were distributed to representatives, male or female, of each house. Overall, we discuss how Kayapó behavior as seed dispersers affects the growth and flourishing of newly brought coconut saplings in the Kayapó village. It will require additional research once the trees come to fruit-baring age, to determine whether and how coconut becomes an important food source for the Kayapó. We report on how the coconuts palms that existed prior to our first and second shipment were distributed among the indigenous families and we report on how the first year's shipment thrived.

To this end, we searched the villages thoroughly, interviewed representatives from each household, and took note of each coconut palm, and inquired, household by household about each palm. We did not search the crop-fields, beyond the village limits, and physically separated from the village, but always asked the Indians if they had any coconut palm in those areas in our interviews. The palms were divided into two groups: fruit-producing adult palms invariably showing a visible trunk above the ground level, and juveniles. Among the juveniles, we made a distinction by reconfirming with Indians in our interviews, between those that were brought by us in the first expedition and the ones that they acquired by other means.

As we noticed common patterns that inhibited coconut growth and survival, we began to transmit effective techniques to bolster coconut growth. For example, in Moikarakô a Kayapó man demonstrated how to cut the damaged old roots of sprouted coconut seeds before planting, in order to give them a new opportunity to grow fresh roots avoiding termite invasion that could cause the seedling death. In another case we made an example of one household who's

Table 1. Distribution scheme of the 5,000 coconuts seedlings by the NGO Protected Forest Association (AFP) in November 2007 with the support of the Brazilian National Health Foundation (FUNASA). We considered both the size of each village's population and the difficulty of access in determining the number of seedlings to send to each village.

\begin{tabular}{lccc}
\hline Village & Population & $\begin{array}{c}\text { Difficulty of } \\
\text { access }\end{array}$ & $\begin{array}{c}\text { Number of } \\
\text { seedlings received }\end{array}$ \\
\hline Kikretum & 850 & Low & 1200 \\
Moikarakô & 400 & Medium & 700 \\
Aukre & 450 & Medium & 800 \\
Kokraimoro & 450 & Low & 700 \\
Pykararankre & 200 & Low & 400 \\
Kendjam & 200 & High & 300 \\
Kubenkrankei & 200 & High & 300 \\
Kokokuedjã & 150 & Low & 300 \\
Las Casas & 270 & Low & 250 \\
Rio Vermelho & 10 & Medium & 50 \\
\hline
\end{tabular}


members build a small fence around their planted coconuts in order to inhibit animals and children from tampering with the seed. We also discussed the importance of abundance of water and light in the initial stages of seed growth.

Lastly, we also conducted a coconut workshop in each village in which we attempted to disseminate non-native ways in which to use coconut products with crops indigenous to the Kayapó diet, namely, manihot. We brought dried and shredded coconut and tapioca starch (made from the manihot root) from the city and made Brazilian bijous, tapioca pancakes, fried with butter and rolled in shredded coconut. The intention was to encourage the Kayapó to use coconuts in ways other than merely drinking the coconut water. The participants in each village differed significantly. In Kikretum, we announced our intention for the workshop to a village leader and a school teacher, a Kayapo man of about 30 years old. No formal announcement was made. The school teacher came and participated in making the bijous with us. He proved to be quite proficient. About an hour after we started, some nearby Kayapo villagers, mostly teenage boys, realized they could try this different delicacy, and a small crowd gathered to help us eat them.

In Moikarakô, we announced the bijou-making workshop, again, rather informally, to a handful of village dwellers. We hoped the word would spread. We held the workshop in the large shelter in which we were staying on the outskirts of the village, by the path to the river. Often, children and a few friendly adults hang out near our shelter at any given time. We make friends, they are curious to see how we are, what we have. On the day we started the workshop, small groups of children began to trickle in. We do not know how the word spread, or if people were just walking by on their way to the river, but a substantial number, maybe 25 children, boys and girls between the ages of 5 and 12, hung to the sides of the shelter and eagerly watched as we explained the bijou-making process. They were mostly interested in trying the novelty, which we split up, batch after batch, among them. They argued and pushed to get some in their hands. After a few demonstrations, we asked for a volunteer to try to make the bijou. A boy of about 10 volunteered and successfully made a bijou, which was split among the children. Within an hour of the workshop, the children got so rambunktous to try the bijou, and the raw shredded coconut in package, that we had to distribute the remnants and close shop.

By the time we reached Aukre village, we had some trepidation about the effects of the coconut workshop. In this village we were best known (Feder and Salm conducted graduate fieldwork in Aukre) and we feared not having enough to feed everyone. We decided to have a discreet bijou-making session with only our closest Kayapo friends. We reasoned that if they understood the process, that they could convey the message as they wished, to other village members. In the future, if we hold workshops, especially those involving food, we will plan differently. First, we will explain our intention to the village leaders and ask their advice, taking into consideration the amount of supplies we have. We imagine they will want to hand-select a few representatives to join us discreetly, and learn the process, after which it can be spread through the village.

\section{Cultivated trees distribution within Kayapó villages}

Based on observations made in our November 2007 field trip, we were concerned that most Indians planted their coconut seedlings right behind their houses where competition with other cultivated trees may hinder the palms development. Nevertheless, this seems to be the area were most of their cultivated trees are concentrated. This area, the household sphere, is regarded by some anthropologists as being a female sphere (Léa 1994). In July 2008, one of us (Rodolfo Salm) visited two other Kayapó villages, Kokraimoro and
Pykararankre, which received the first shipment of coconut seedling from our program in November 2007. RS took the opportunity to quantitatively describe this problem estimating the position of the previously existing and newly planted coconut trees in relation to other cultivated trees.

In Kokraimoro and Pykararankre villages, all cultivated threes were counted along eight transects departing from the center of the village to eight cardinal directions (N, NE, E, SE, S, SW, W, NW) until the village limits with surrounding wild area. This was defined as the point where cultivated plants are no longer found, and this limit is quite clear for the visited Kayapó villages (Figure 1). All cultivated trees beyond the seedling stage up to $10 \mathrm{~m}$ on both sides of the transect were identified to genus or species, with the aid of a Kayapó assistant, in $20 \mathrm{~m}$ intervals. Perpendicular distances from transects was not measured, unless the plant appeared to be close to the distance cut-off point to ensure census accuracy. Sky openness measurements were made every $20 \mathrm{~m}$ along the transects with a spherical densiometer (a pocked-size concave mirror with 96 divisions). They were chosen as a proxy for the village's light environment.

\section{Results}

\section{Coconuts distribution among the Indian families}

In our survey in November 2007, we found that all the palms in the three villages, Kikretum, Aukre and Moikarakô, including those of the first shipment, were the property of one household or another. Although we determined that the 600 seedlings delivered in the first shipment in April 2006 would be divided into two groups, one that would be common property to all village members and another that would be divided equally among the village families (households), we did not supervise plantation work and the villagers decided otherwise. Nineteen months later, the group of seedlings of the first shipment that our own team personally planted around schools and pharmacies in the villages were the only ones that could be considered of common domain. The coconut saplings that we set aside for the village as a community were distributed (probably opportunistically rather than equally) to individual families after our departure.

In the three Indian villages that we visited, all adult coconut trees planted prior to our first shipment (according to the interviews that we made) belonged to a select few families and the coconut fruit distribution was highly concentrated among these family members. A large percentage of families had no coconut trees around their houses or in their gardens. Adult coconut tree distribution was most highly concentrated in Kikretum, followed by Aukre, and was substantially less pronounced in Moikarakô because of a shipment that was distributed to the community by FUNAI in 2001. If all of the juvenile coconut trees from shipments prior to ours, and achieved through other means are to survive (again, excluding those introduced by our program) to the adult stage, then the adult coconut tree population will increase more pronouncedly in Kikretum (to 122 trees, a $430 \%$ increase) than in Aukre, (to 41 trees, a 17\% increase) or in Moikarakô (to 85, a 16\% increase). It also follows that inequality in distribution among families will also likely be reduced as new families acquire saplings.

As expected, because our first shipment of seedlings was planted in the commencement of the dry season in 2006, the mortality of seedlings planted from that shipment was very high. From the 600 coconut seedlings given to each village in November 2007 we found only 59 saplings alive in Kikretum, 86 in Moikarakô and 80 in Aukre. Nevertheless, assuming that all the coconut saplings that survived the first year from the first shipment will reach maturity, they represent a remarkable increase in the projected number of adult coconut palms in the three visited villages (48, 195 and 101\% in Kikretum, 
Table 2. Distribution of the property of the existing coconut trees population in the Kayapó villages of Kikretum, Moikarakô and Aukre. Projections were made assuming the survival and development to the adult age of all young coconut palms brought on our first shipment of coconut seedling in 2006.

\begin{tabular}{|c|c|c|c|}
\hline & Kikretum & Aukre & Moikarakô \\
\hline Number of houses & 61 & 33 & 32 \\
\hline Adult coconut trees & 23 & 35 & 73 \\
\hline Pre-existing young coconut trees & 87 & 18 & 12 \\
\hline Percentage of adult coconut trees owed by the $10 \%$ wealthiest houses in coconut trees & $71 \%$ & $56 \%$ & $24 \%$ \\
\hline Projected percentage of coconut trees owed by the $10 \%$ wealthiest houses in coconut trees & $32 \%$ & $39 \%$ & $23 \%$ \\
\hline Surviving young coconut palms brought at the first shipment of coconuts seedlings in 2006 & 59 & 80 & 86 \\
\hline $\begin{array}{l}\text { Projected percentage of coconut trees owed by the } 10 \% \text { wealthiest houses in coconut trees, considering } \\
\text { the first shipment }\end{array}$ & $29 \%$ & $33 \%$ & $22 \%$ \\
\hline
\end{tabular}
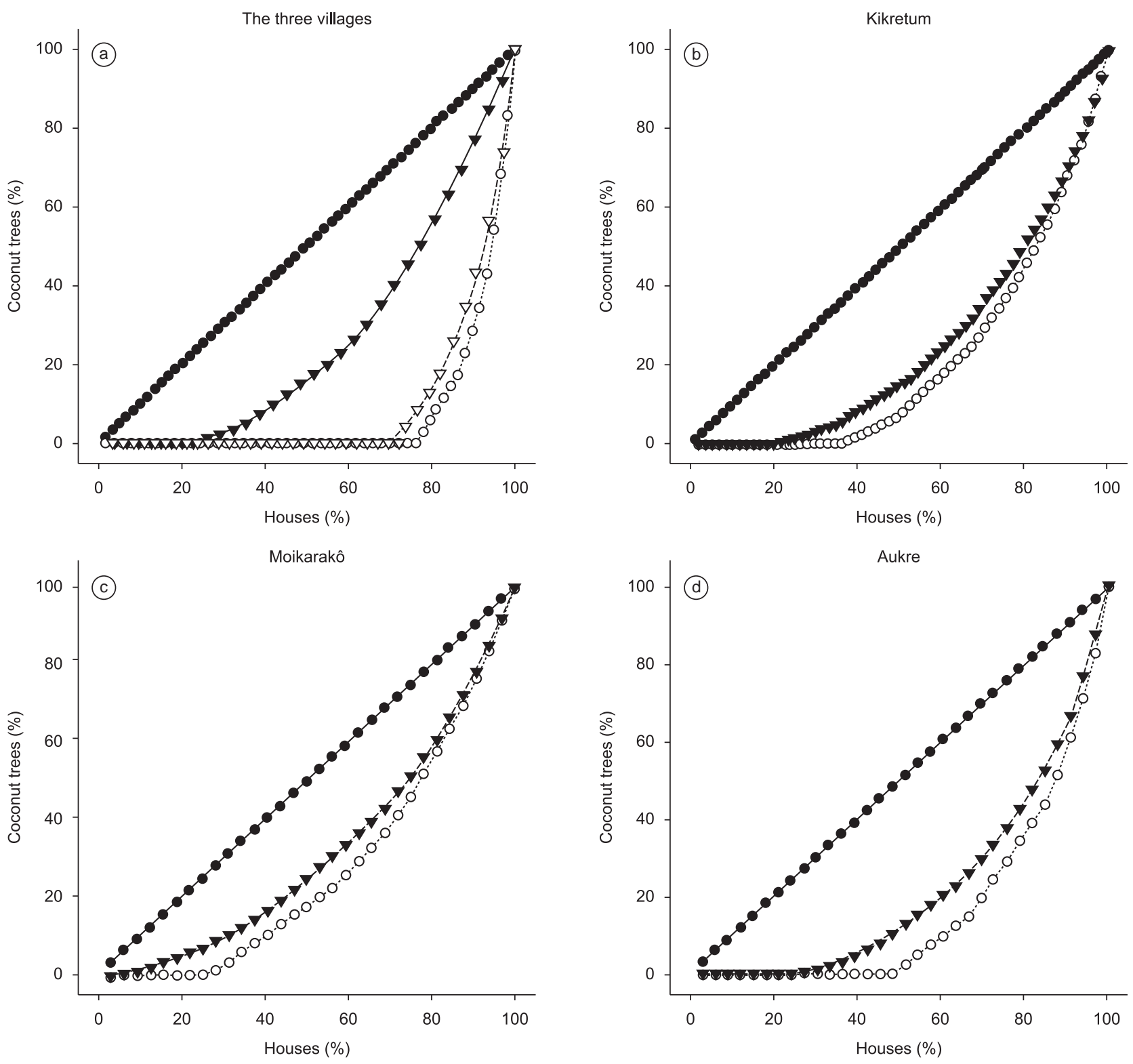

Figure 3. Graphical representation of the cumulative distribution (the Lorenz curve) of coconut trees: at (a) the three studied villages (Moikarakô represented by the filled triangle, Aukre by open triangle, and Kikretum by open circles); (b); (c) and (d) representing the projected cumulative distribution in Kikretum, Moikarakô and Aukre (filled triangles and open circles represent the projected adult population considering all saplings, including those brought by us in the first shipment of coconut seedling in 2006, or only those brought by others, independently of our coconut support program, usually Kayapó themselves). The diagonal straight line represents perfect equality in distribution of coconut trees between all households. 
Moikarakô and Aukre, respectively), and a substantial reduction in the inequality in access to coconuts (Table 2, Figure 3).

In Moikarakô, due to a previous provision of dwarf coconut seedlings by FUNAI in 2001, there is a much more even distribution on the property of adult coconut trees in this village. This highlights the potential effects of actions such as ours toward the increased equality in coconut distribution and the likelihood that coconuts will become a more important foodsource in Kayapó villages in the future. Meanwhile, it is clear that some Kayapó families living in Kikretum that do not already have coconut trees are making a small effort to import them from Brazilian cities (since the seedlings are rarely produced by the Indians themselves in the villages). Kikretum stands alone in these efforts, we surmise, because, was we pointed above, it is the only one of these three villages with easy access to a Brazilian town. Still, meanwhile, few families have limited access to coconut fruits while the majority of people have little or no access at all. Our efforts to bring coconuts to all families is changing this reality, hopefully to the benefit of everyone.

\section{Cultivated trees distribution within Kayapó villages}

In our second study in Pykararankre and Kokraimoro, which we visited in July 2008, we examined the planting position of coconuts vis-avis other cultivated crops in the vicinities around households. We note that mangos (Mangifera indica) were the most abundant species, corresponding to more than $20 \%$ of the cultivated trees. In Kokraimoro village, genipapos (Genipa Americana), whose fruits are used for body painting were represented by the same quantity of trees, followed by ice-cream-beans (Inga spp.) and coconuts. Urucum (Bixa sp.), the $11^{\text {th }}$ most abundant species in Kokraimoro, is another tree whose fruits are used for body painting. Of the 16 cultivated tree genera found in Kokraimoro, eleven were native to South America: Genipa, Inga, Theobroma (cocoa and cupuaçu), Carica (papaya), Psidium (guava), Rollinia (araticum), Anacardium (caju), Bixa, Euterpe (acai berry), Pouteria (pariri) and Oenocarpus (bacaba). All the remaining five genera originally came from Asia: Mangifera, Citrus (lima, lemon and

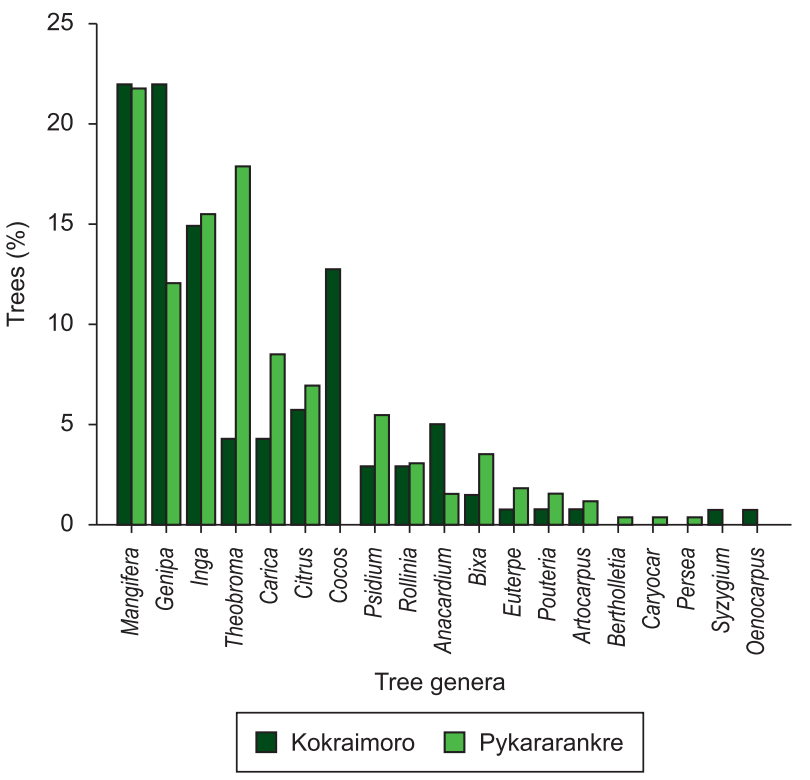

Figure 4. Frequency of cultivated tree genera found in the eight $20 \mathrm{~m}$ transects laid in the Kayapó villages of Kokraimoro and Pykararankre. The exotic genera in South America were written in capital letters. tangerine), Cocos, Artocarpus (jaca fruit) and Syzygium (Java plum). In Pykararankre village, after Mangifera, Theobroma is the most abundant genera followed by Inga, Genipa, Carica, Citrus, Psidium, Bixa, Rollinia, Euterpe, Anacardium, Pouteria and Artocarpus. In this village, among the cultivated native trees we also sampled one individual Bertholletia (Brazil-nut tree) and one Caryocar (pequi), beside one tree of a Central American genera: Persea (avocado). No adult coconut tree was sampled in Pykararankre (Figure 4).

Examining the density distribution of coconuts and all other cultivated trees pulled together along the axis that departs from the village centre to its limits with adjacent wild area, we notice that these trees are mainly concentrated on the first $80-100 \mathrm{~m}$ behind the houses and that both old and new coconuts are planted even closer than that (Figure 5).

We believe that the Indians give a great value to coconut palms and generally plant them very close to their houses both because of practicality and control in the access to their fruits. However, because this area also concentrates the higher densities of several other tree species, it is also characterized by the highest levels of shade than
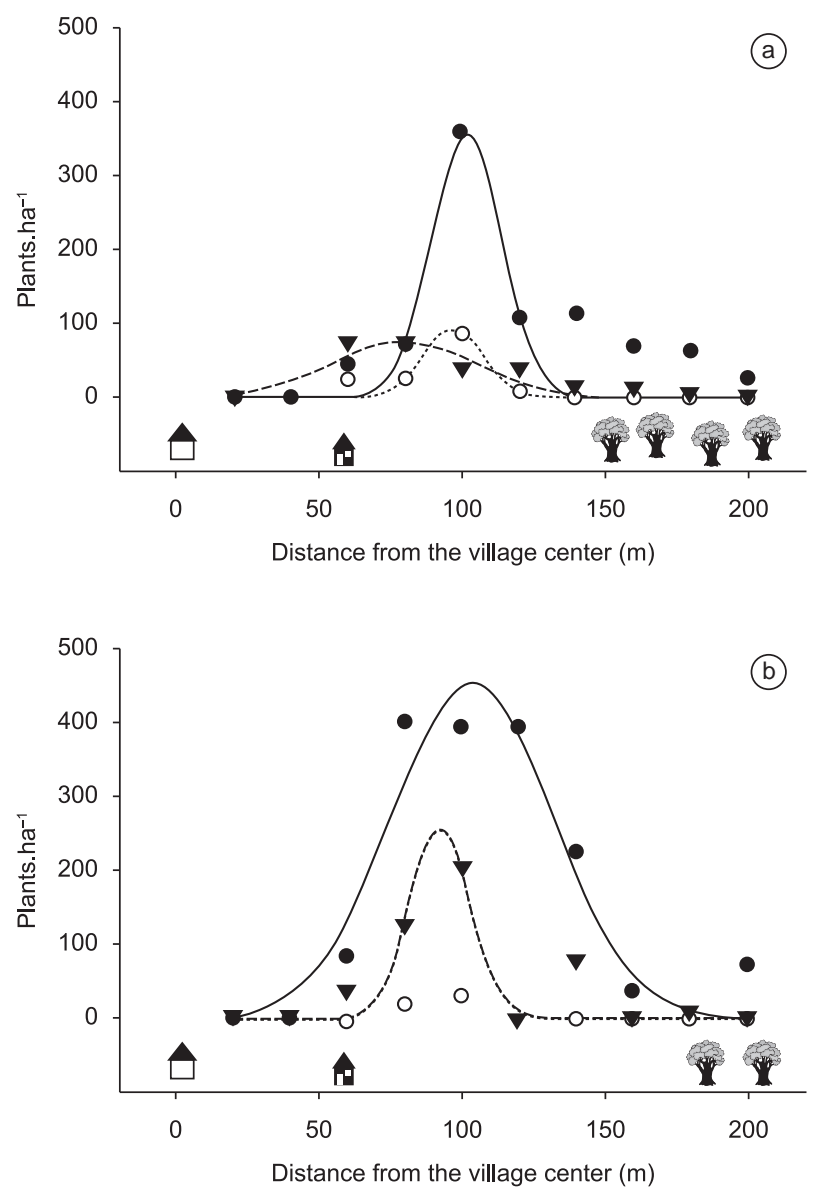

Figure 5. The density of coconuts and cultivated trees in the Kayapó villages (a-Pykararankre, b-Kokraimoro). The plants were sampled via the transect departing from the center of the village to eight cardinal directions $(\mathrm{N}, \mathrm{NE}$, E, SE, S, SW, W, NW) until the village limits with surrounding wild area. Pre-existing coconut palms are represented by open circles and dotted lines. Filled triangles and dashed lines represent the new coconut shipped to these villages by our coconut cultivation support program in November 2007. Filled circles and continuous lines represent the amount of all other cultivated trees combined. 

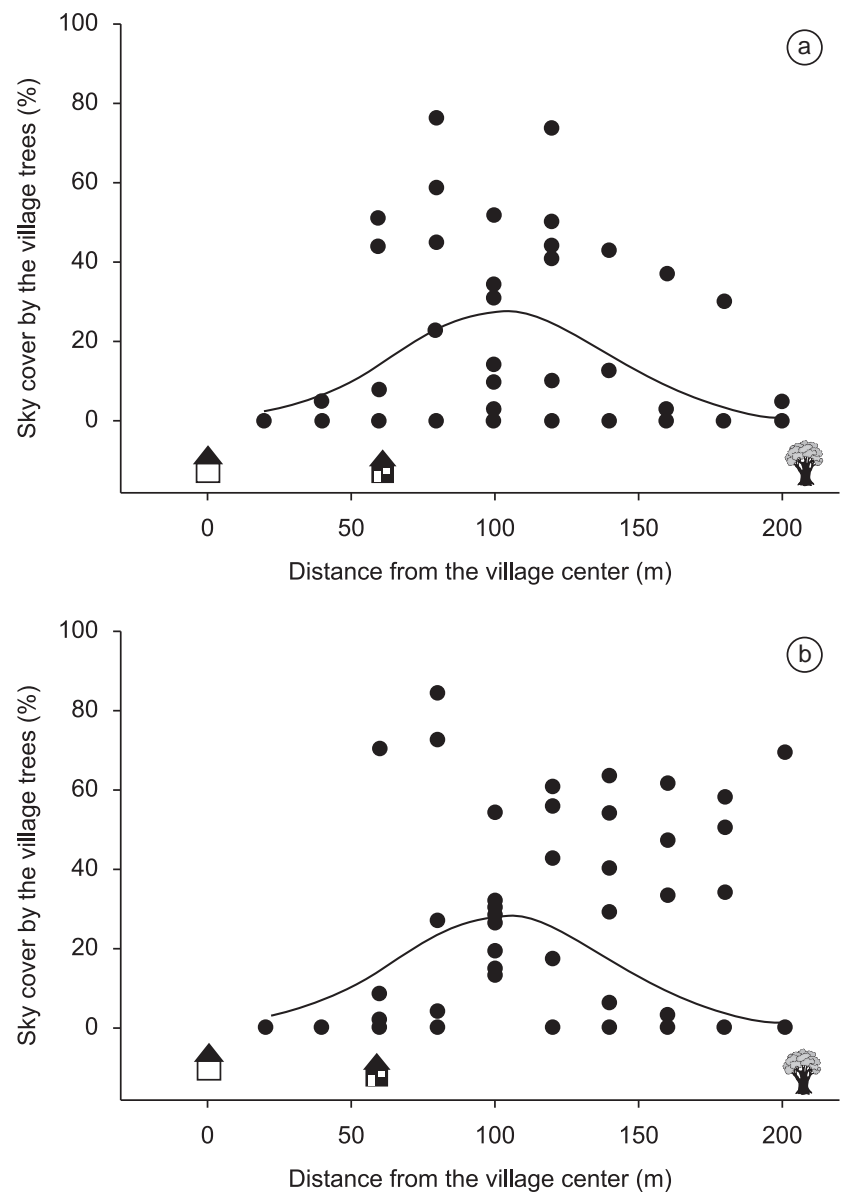

Figure 6. Percentage of sky cover in the Kayapó villages (a-Pykararankre, b-Kokraimoro). Sky cover was measured along transects departing from the center of the village to eight cardinal directions (N, NE, E, SE, S, SW, W, NW) until the village limits with surrounding wild area using a spherical densiometer (a pocked-size concave mirror with 96 divisions).

anywhere else within the villages (Figure 6), conditions that are unfavorable to growing the coconut palm.

\section{Discussion}

In this study, by definition we adopt an ethnoecological approach toward sustainable development, or specifically, an ethnobiological approach (Gragson \& Blount 1999) in which "ethnobiology is thus based on an interdisciplinary study of the relationships of plants and animals with human cultures, including past and present relationships between peoples and the environment" (Rist \& Dahdouh-Guebas 2006). We consider the cultural specificities of the Kayapó that interrelate with the ecological system to investigate the propagation of coconut culture in this area toward rain forest conservation.

J.D. Unruh, writing about the effect of different patterns of land use on the process of diffusion of valuable plant species, knowledge or ignorance about the attributes of specific tree species at a given point in time, may interact favorably or unfavorable in man's dealing with the plant so that the opportunities for proliferation are gained or lost (Unruh 1994). This can be manifested in different ways. Subsistence populations living in high risk conditions can have very immediate needs which preclude even modest additional investments of time and labor into tree planting and maintenance. Furthermore, the deliberate planting and management of trees by local populations in the tropics will, to a large degree, be subject to the availability of time, energy, money, and inclination, as well as to the limited and changing priori- ties of development efforts in highly variable ecological, economic, social and political environments (Unruh 1994).

Kayapó behavior both encourages and discourages the growth of coconut culture in a variety of ways, intentionally and unintentionally. As we learned in the second part to our study, the Kayapó generally cultivate fruiting trees in the first $80-100 \mathrm{~m}$ behind their houses, as shown by the censuses that we made in July 2008 Kokraimoro and Pykararankre villages. These trees include both native and exotic species, cultivated with different purposes from the production of edible fruits to fruits used for body painting, like genipapo (G. americana) and urucum (Bixa sp.). The amounts and proportions of the available trees in the Indian villages do not reflect their desire, precisely. Instead, it is a reflection of their management practices in combination with the reproductive ecology of the species and the plant resources availability. It is easy to obtain seeds of the native species, especially of those found in the surrounding forest like ice-cream-beans (Inga ssp.), acai berry (Euterpe) and bacaba (Oenocarpus). Although this area, as pointed above, is regarded as being a female sphere (Léa 1994), we note that some families (both man and women) will bother cultivating native trees behind their houses that are normally readily available in the wild. This is obviously to bring the fruits in closer reach, but we speculate that it is also to incorporate them into the family's private property, thus securing a food source as these wild resources become more scarce.

Other species are native to South America but are domesticated or semi-domesticated, like genipapo (Genipa americana), cashew (Anacardium occidentale), papaya (Caryca papaya), cacao (Theobroma cacao), biriba (Rollinia mucosa), guava (Psidium sp.), urucum (Bixa sp.), сириасu (Theobroma grandiflorum), pequi (Caryocar brasiliense), and some varieties of Inga and frutão (Lucuma pariry). Their seeds have to be brought from other human settlements. The exotic species, like mangos (Mangifera indica), species of the genera Citrus, such as lime, lemon and orange, coconuts (Cocos nucifera), jaca fruit (Artocarpus heterophyllus), avocado (Persea americana) and Java plums (Syzygium cumini), at some point were all acquired from non-indigenous people.

We asked an Indian why there are so few representations of avocado and jaca fruits species since it is so easy to produce these fruits' seedlings from adult producing trees. He answered that the Kayapó do not appreciate these fruits very much, and suggested that a few adult plants are sufficient to fulfill their small demand for these fruits.

On the other hand, in the visits to the Kayapó villages, many Indians manifested the desire of receiving seedlings of species of the genera Citrus, suited for juice production and rich in vitamin C, but technically they are not easily grown from seed. Such difficulty might explain the relative rarity of these species given that their fruits are very much appreciated. Mango trees, the most abundant cultivated trees in Kokraimoro and Pykararankre, are generally so abundant in all Kayapó villages that, during the fruiting season, which lasts from November to January, many of the mangos fall to the ground and are eaten by animals and insects, and left to rot.

Eating a coconut from the tree of another person's family without permission might result in a social fuss (we witnessed this). In contrast, during its fruiting season, eating a falling mango fruit from the village floor is trivial. This is because coconuts, despite being appreciated by the Indians, are still scarce and, as our results have shown, every coconut tree is a property of one family or another, and they are defended as such. Furthermore, what we have seen in Kikretum, Aukre and (less intensively) in Moikarakô village is that coconuts are not just scarce but the property of these trees is also concentrated in the hands of a few families.

We hypothesize that such inequality hinders the endogenous multiplication of coconut trees within the Kayapó villages for dif- 
ferent reasons. First, the inequality found in the distribution of the trees' property means that most families without access to the fruits do not even have the opportunity to produce coconut seedlings from fruits, while those families where trees are most concentrated might not do so because they already have more coconut palms the average person in the village. Furthermore, with several families having few or no access to coconuts, new ways in which to use coconut products, like the use of dried and shredded coconut with tapioca starch made from the manihot root, have more difficulties to naturally propagate. There is little to no chance in reaching equality in distribution and the minimum production level to reach the point of breakthrough particularly in more remote villages (unlike Kikretum whose individuals are taking measures to bring in coconuts from the nearby Brazilian town) without external assistance such as ours. We believe the Kayapó welcome our support and we believe such support is favorable, though our motivations are likely to be different. We believe coconut reproduction will improve Kayapó health and rain forest conservation, and they (both man and women of all ages) like the novelty and the taste of coconuts.

We recognize that Kayapó and our own different motivations for supporting importation of coconuts, while creating a win-win situation, does not necessarily support interculturality in our methodology and furthermore, may hinder the success of coconut culture. Below we discuss how our lack of interculturality in planning this project may have a negative affect on coconut growth as well.

\section{Difficulties in coconut growth}

As we expected, due to the delays that influenced our decision to plant the first shipment of coconut seedlings only at the end of the rainy season, the mortality among those seedling was high. Indeed, from a strictly agronomic point of view, the mortality of $85-90 \%$ of the coconut seedlings of the 2006 shipment in Kikretum, Moikarakô and Aukre is, no doubt, a failure. However, from the optics of seed dispersal, a process naturally characterized by extremely high mortality rates (Howe 1982), the survival of $10-15 \%$ of the planted coconut trees can be seen as a success. Thus, despite the difficulty that we had to implement the first phase of this project in a more appropriate time of the year, the results of the first shipment are significant and long-lasting. Now, many more families will have access to coconut fruits, and will have the choice to save and replant coconut seedlings themselves until they reach their desired amount. Our results might have been different if the Kayapó were more proactive in caring for these coconuts by watering them.

Although drought was certainly a major source of mortality, in many cases, other sources of mortality apart from drought were identified, and it is uncertain how much they will be avoided in the second round of seedling planting. To appreciate their actual importance it would be necessary to follow for some time the fate of a larger number of seedlings but, unfortunately, at the moment they have to be treated anecdotally.

In the November 2007 field season campaign we noticed several cases in which care for the seedlings was evident. Some were watered and a select few were protected from predators with fences. Although the data that we have is not suitable for a quantitative description of the relative importance of various causes of mortality among the seedlings, we can assert with certainty that the drought of the first year was a major source of mortality. Many of the seedlings that survived were planted in especially favorable places like the naturally humid soils or in the proximity of water taps and other sites where seedlings benefited from water run-off where people bathed or washed dishes. Therefore, considering that the 2007 campaign (in which we took 2.700 seedlings of coconut to these three villages) was made in the beginning of the rainy season, we were certainly much more success- ful, although we had no opportunity to quantify seedling survival at the second shipment.

It was also troubling to us that many of the surviving coconut seedlings of the first shipment in 2006 were planted below large trees, especially mango trees, which cast heavy shadows. Ironically, such a position might have been beneficial to some of the seedlings planted at the end of the rainy season: Their survival in the first dry season might be explained by the shadow's protection from the baking sun. Nevertheless, coconuts demand good insulation to develop, and such a position in the shadow eventually will hinder their proper development to the adult age. Most adult Indians clearly understood the necessity of direct sunlight for the palms. Sometimes, because we explained to them that the seedlings need good insulation to survive, they transferred the plants to more suitable places. In other cases they stated the intention to cut down branches of higher trees (or even the tree as a whole) after the coconut seedling grows to a more resilient size, to allow sunlight through. As we have repeated throughout this article, coconut trees are very much appreciated and we believe that it is because of this that some Kayapó prefer having these palms close to their houses, despite the fact that such proximity may hinder tree growth.

Another main aspect of coconut planting that we discussed with the Indians was the distance between the planted seedlings. The literature on coconut culture recommend that the palms should be planted at least 6 meters one from the other so that there would be no interference of one plant's leaves on the other's (e.g. Pezzopane et al. 2003). However, many Indians preferred to plant them much more closely than recommended. Although we attempted to explain the importance of spacing, because the coconuts are grown for the subsistence consumption of their fruits, the Indians do not (and actually should not) follow a commercial rationale. Therefore, other factors beside maximum productivity per plant are considered in making the conscious choice to clump the planted seedlings in certain areas, like the facility of access to their future fruits, the control to the access of these fruits and even the role that planted coconut seedlings can play on determining the limits of their gardens, as cited above.

In some areas, it was visible that the children, playing with the palm leaves, killed several plants. Some Kayapó children also have the highly destructive habit of unburying the planted seedlings to eat the interior of the germinating seeds, which is somewhat sweet (the developed saplings do not have the sweet endocarp and no longer suffer from this kind of predation). Another unexpected source of mortality came from the capybaras (Hydrochoerus hydrochaeris), large rodents, which are naturally abundant at the region of the Fresco River, where Kikretum village is settled. According to the people of this village, wild capybaras dug up and ate several seeds during the night. Considering that rodent predation is generally a major source of seed mortality on native palms (Smythe, 1978), it should not be surprising that the largest rodent in the world, when meeting one of the largest palm-seeds, inflict such a high mortality to the palms. In Moikarakô and Aukre villages, which are placed besides the Riozinho, a smaller river where capybaras are much less abundant, that source of mortality was not reported. This difference in rodent predation might explain the lower survival of coconut seedlings in Kikretum, compared to the two other villages.

One measure that we tried to take, rather paternalistically, backfired, and maybe to the advantage of coconut growth. We understood FUNAI's recommendation that under harsh circumstances (due to the proximity of the dry season when we first planted in April 2006) the private seedlings would do better than the collective owned ones, as a hypothesis. We decided, on our own accord, to test this hypothesis by giving an identical number of coconut seedling to the three villages, that were to be divided into two groups: a) seedlings of com- 
mon property to all village members; and b) seedlings that would be divided equally among households. Thus we did not strictly follow the recommendations of FUNAI, nor did we ask for the advice of the local Kayapó recipients of the coconut seedlings. In doing so, we can be construed as acting paternalistically according to Dahdouh-Guebas, et al. (2003) or even be said to have "unacknowledged" indigenous attitudes on the matter. As a result, such seedling division plan generated some protest among the Indians of the larger village, Kikretum, which received proportionally less coconut seedlings. However, our wishes to divide coconuts into private and community property were ignored anyway, in that individual families assumed the seedlings that we had separated out for common property after our departure, anyway. Although these results may be frustrating to us, as we had hoped to test which flourished better and increased access to coconuts, common or private property, in retrospect we believe that the Kayapó knew best that coconuts would survive more readily if individuals cared for them. We cannot be sure, but if it is true, then it would support FUNAI's hypothesis that privately distributed seedlings would fare better.

There are several factors responsible for preventing coconuts from becoming valuable without foreign support. Focusing on the coconuts biology, the relative failure of coconuts to become established as an important nutritional source to the Kayapó can possibly be understood in light of their differences in seed-dispersal. There is a fundamental difference in reproduction between these plant species, with obvious ecological consequences: while a new mango tree can be easily produced by eating a fruit and simply dropping the pit to the floor in a suitable place (and many pits are dropped!), in the case of coconut trees, it is the seed itself, which is consumed, and thereby destroyed in the process of consumption. Therefore, humans have to consciously decide to spare a fruit, which nowadays are generally avidly consumed when still green, until it matures, after which this seed must be put in a protected and humid milieu, where the seed sprouts, then transferred to an appropriate area for the development of the adult palm. We have seen in the villages that, because the total fruit production is low, the fruits are generally consumed while they are still green and virtually none is reserved for seedling production.

Similar is the relationship between the agoutis and brazil nuts, for example and other plants predated and dispersed by the same agents, when successful reproduction is a function of the balance between a seed disperser/predator's decision to eat the seed or save it for "latter consumption" (Forget 2006, Jorge 2007). In the case of coconuthumans relationship, "keeping the fruit for latter consumption" means to save the seed for the development of a coconut seedling and the growth of a new adult tree. Such decision depends fundamentally on the fruit abundance and, unfortunately to rare coconuts trees in hungry and thirsty indigenous villages, scarcity favors the decision of consuming rather than saving for the future, in both agoutis and human beings alike, unless there is a conscious and determinate choice to act otherwise.

\section{Self-Reflection and planning for the future}

Despite our full awareness of the importance of the local viewpoint in initiating changes to the local system, we initiated a project that can be construed in a variety of ways that range from paternalistic to intercultural (Dahdouh-Guesbas 2003).

As we stated above, our goal with the coconut-planting project is to act upon our perceived connection between sustainable lifestyle and the survival of Kayapó culture. Our intention is to run this project interculturally, avoiding the kind of paternalism that gives local communities goods and money without their participation in the planning, implementation and monitoring. Nevertheless, due to small funds and little time, we were not able to obtain the adequate resources to engage in a long-term intercultural project from the onset, and nevertheless felt that coconut shipments without local participation in planning was still relevant.

Following Dahdouh-Guebas et al. (2003) typology of ontogenetic approaches to ethnoecology, we are "paternalistic" in that, rather than generating ideas together about how to maintain the health of Kayapó society, and therefore the rain forest, which is also a Kayapó concern, we took a fast approach based on our limited time and resources to bring coconuts to the Kayapó, based largely on one-sided decisions. If given the time and resources, we would optimally have facilitated surveys in which we could have generated techniques of expanding coconut culture with Kayapó support and insight. In this sense we would have taken traditional knowledge, such as that used in the Kayapó gardens and crop-fields, as a starting point from which could be 'updated' by science - by the introduction of a selected variety of an exotic plants. Furthermore, although we initially discussed the coconut project prior to its implementation with one of the benefited villages, Aukre, critics of this project questioned to what degree the impetus to start the coconut project came from the Kayapó themselves. In fact, when food security was first discussed among the Kayapó, some suggested the possibility of cattle ranching. We deliberately privileged their suggestion of the growth of coconuts because it was compatible with our conservation goals.

We could be accused of being essentialist in that we choose to invest in coconut planting, which in the short-run requires little indigenous participation, and in the long run requires no maintenance and allows the Kayapó to carry on with their own cultural activities. The alternative is to invest in capacity-building programs towards their engagement in commercial activities that include the Kayapó at all levels, but may change the essence of their day-to-day activities.

We foresee capacitating forest dwellers to generate an income from renewable forest products while maintaining the health and nutrition of their own population. In other words, the Kayapó themselves must manage their natural resources vis-à-vis their population growth. Ideally, we advocate that we, as part of the international community, must provide training, with informed consent of Kayapó leadership, so that traditional knowledge may be effectively linked to making a sustainable income on the international market in a way, and to a degree that the Kayapó deem appropriate. We recognize that the problems of a lack of societal participation in issue-setting and its application to concrete development goals are almost the same as in the case of disciplinary-based knowledge production (Rist \& Dahdouh-Guebas 2006).

We believe the Kayapó still have room to expand their population as their land mass is great, and might need to do so to defend themselves and their land from invasion of non-sustainable developers. It is urgent that they acquire the skills and tools necessary to make forest management decisions for themselves. However, due to lack of funds and dwindling health coupled with population growth, we, the non-native, and in this case, scientists, make capacitating decisions without fully engaging the population in decision-making, upholding clearly a form of paternalism. Though our project may be largely construed in this way, we see a great possibility for the Kayapó to take an increasing role in planning and determining future coconut imports according to culturally-defined needs. We, as scientists, will serve to train select Kayapó in carrying out ethnoecological research aimed at increasing their own knowledge about coconut to human populations and the benefits to local health and rain forest conservation. Eventually, our role will diminish. As such, they will learn the scientific methods in propagating the species, and be able to calculate to what end they want to increase production without assistance from the dominating culture. 


\section{Conclusion}

Kayapó Indians are not more dedicated to increase coconut production themselves at this time, for several reasons. First, coconuts are not a traditional food source for the Kayapó so there is little sociocultural value in making this fruit important, particularly due to the unequal distribution of coconuts up to now. Secondly, the distribution of coconut trees is highly concentrated to a few families, and the efforts (distance and cost) necessary to obtain seedlings from outside sources are too great. In order to foster an environment in which families eat coconuts and set a few aside for replanting and growing new trees, it will require further shipments of coconuts coupled with local planning and participation. As valuable trees become established within land-uses, there are thresholds beyond which certain feedback can be engaged, magnifying the process of diffusion (Unruh 1994). Because the deficit of coconuts is so great at the moment, we believe that new shipments of coconuts should be continued each year at the commencement of the rainy season, gradually coupled with the facilitation of Kayapó planning and participation, if they would like coconut growth to continue. In fact, not increasing Kayapó participation in coconut planning would be propagating Kayapó dependency on hand-outs for food from the dominant culture. While we believe that assistance is necessary in difficult situations of exponentially increasing deforestation and dwindling Kayapó nutrition, we believe that Kayapó participation is essential in the long-run.

The external help for the culture of coconuts in the Kayapó lands in the form of large shipments of coconut seedlings to be distributed equally among the households can aid the endogenous propagation of coconuts trees in these areas by providing an ample source of seeds for the palm multiplication. Simultaneously, according to our financial possibilities we should begin dialogue with Kayapó leadership, and based on intercultural accordance, capacity-building, and intercultural programs that serve to develop comprehensive interaction for computing the availability of coconuts (and maybe other nutritious fruit trees) vis-à-vis local population growth. Within a few years, coconut trees and Kayapó skills should both reach acceptable levels such that the Kayapó may begin to plan for themselves how many seeds to set aside for replanting each year in order to reach or maintain the level of coconuts per person suitable to their own specified needs. It is impossible to determine how many shipments of coconut sapling we should make before we can state that there is a sufficient amount of palms surrounding Kayapó villages so that its culture can propagate itself endogenously. This is something that the Kayapó must ultimately decide for themselves.

In Mac Chapin's controversial article (2004), he discussed the relationship between the large, well-funded NGOs such as Conservation International, and the traditional peoples living in the territories that the conservationists are trying to protect. He pointed to a growing conflict of interest between these two groups. He quoted one member of these NGO's as saying, "Quite frankly, I don't care what the Indians want. We have to work to conserve the biodiversity", to summarize what he believes that the philosophy of these organizations are. In response to Chapin, Chernela (2005) replied that such a relationship between NGOs and traditional peoples can be mutually benefiting for both groups, citing, as an example, the alliance of between CI and the Kayapó for territorial surveillance.

The critical role of indigenous peoples for Amazonian conservation is increasingly challenged by their growing integration into the global market. Among the Kayapó of Aukre village, this was demonstrated to produce differentiation at individual and household level, potentially affecting traditional patterns of natural resource use (Morsello 2002). Introducing manufactured objects to indigenous territories also demonstrates environmental pollution (Feder 2001), a concern of which there have been attempts to mitigate. For example, an NGO attempted a project of eco-tourism in Aukre village based on small groups of university students to promote more sustainable and less deleterious income generation and market integration (Zanotti \& Chernela 2008). Unfortunately, since the 2004 experience discussed, due to practical reasons there were no field courses in recent years. In the past, the courses were always restricted to one or two villages.

Although this coconuts seedling donation program has been entirely funded by the Brazilian governmental organizations, FUNAI e FUNASA, it was made possible at first, due to the contact that we, the independent scientists, made with the Kayapó through the Pinkaití research station, established in the Kayapó area in cooperation with Conservation International (Zimmerman et al. 2001).

We took the opportunity to foster Kayapó health and rain forest conservation simultaneously, albeit, somewhat paternalistically, by initiating a coconut-planting program in the Kayapó Indigenous area based on a decision made by few Kayapó leaders, FUNAI agents and the scientists. In the meeting with Aukre Indians, when we first discussed the coconut idea, different suggestions were made by some Kayapó, like, for example, supporting cattle ranching, what we, as conservationists, did not feel we could support due to its direct association with deforestation. However, we offered what we could do, and the select Kayapo representatives present thought it was an acceptable idea.

At this point, it is essential for us to shift from our paternalistic relationship, towards one of mutual cooperation and understanding. We must engage in dialogue with the Kayapo about the possibility of future shipments of coconuts. We believe it is a good idea to continue shipments for the sake of Kayapo and rain forest health, simultaneously. Having some relationship with the Kayapo already, we also believe that if we presented our reasoning, Kayapo support for our project would continue, if not increase. This would shift our actions from a more narcissistic "gift" bearing our "signature" (Weiner 1985) into a request made by the Kayapo leaders, themselves. Optimally, our relationship with the Kayapo could be a practice of exchange, a negotiation between two parties, rather than an unrequested gift. One obstacle in working with the Kayapo is the limited means of communication and funds that we have. As an independent, not well-funded body, it is impractical to travel to the territories, as such travel is expensive, and the alternatives, communication through short-wave radio and occasional phone contact with select individuals, is very limiting. Unfortunately we see that our position puts us at a disadvantage to the larger NGOs, who, while having the resources to speak with the Kayapó at length, often fail to do so because their funding relies on achieving particular goals created without the Kayapó. Neither is an optimal situation, so we do what we can.

Future studies should focus more deeply on what the Kayapó are thinking, talking and doing about coconuts. At the moment, the Kayapó do not actually care enough about this culture and will likely not change their minds without outside inspiration. That said, they have also received our gifts several times with apparent much enthusiasm. We must confirm our assumptions through dialogue or a social study. Still, investing in a project to allow the full exploitation of the most used palm species in the world, source of food, drink and potentially diverse raw materials for innumerous ends (Harries 1979), for the benefit of a people who is suffering an exponential demography growth (Verswijver 1992) in a limited, closed territory, is surely a positive result. We will continue to seek funding that will increase our ability to communicate with Kayapo leadership toward continuing the coconut project. 


\section{Acknowledgments}

We thank P. M. Arruda, for his dedication to the seedlings transportation and for working on the palms censuses. We are much grateful to A. Jerozolimski and to an anonymous reviewer for important suggestions that improved this manuscript. We are also thankful for the Conservation International (CI-Brasil) that provided part of the logistic structure for our group in the Kayapó villages and the NGOs Protected Forest Association (AFP), and Raoni Institute (IR, Instituto Raoni) which worked with us, for the culture of coconuts as a conservation strategy in the Kayapó Indigenous Lands, supported by the Brazilian National Health Foundation (FUNASA). Above all, we thank the Kayapó Indians for the support to this program.

\section{References}

ALCORN, J.B. 1981. Some factors influencing botanical resources perception among the Huastec: suggestions for future ethnobonical inquiry. J. Ethnobiol. 1(2):221-230.

ANDERSON, A.B. \& POSEY, D.A. 1989. Management of a Tropical Scrub Savanna by the Gorotire Kayapó of Brazil. In Resource Management in Amazonia: indigenous and Folk Strategies (D.A. Posey \& W.L. Balée, eds). New York Botanical Garden, New York, p. 159-173.

CASE, T.J. 1996. Global patterns in the establishment and distribution of exotic birds. Biol. Conserv. 78(1):69-96.

CHAPIN, M. 2004. A challenge to conservationists. World Watch 17(6):17-31.

CHERNELA, J. 2005. Readers' Responses to "A Challenge to Conservationists". World Watch 18(2):17-31.

CUENCA, M.A.G. 1997. A importância econômica do coqueiro. In A cultura do coqueiro no Brasil (J.M.S. Ferreira, D.R.N. Warwick, \& L.A. Siqueira, eds). 2 ed. EMBRAPA, Aracajú, p. 17-56.

DAHDOUH-GUEBAS, F., AHIMBISIBWE, J., Van MOLL, R. \& KOEDAM, N. 2003. Neo-colonial science by the most industrialized upon the least developed countries in peer-reviewed publishing. Scientometrics 56(3):329-343.

DUBOST, G. 1988. Ecology and social life of the red acouchy, Myoprocta exilis; comparison with the orange-rumped agouti, Dasyprocta leporine. J. Ecol. 214(1):107-123.

FEDER, L. 2001. Eco-education: a new plan for alternative development in indigenous societies: case study on the kayapo of Brazil. Dissertação de Mestrado, University of Chicago, Chicago.

FORGET, P.M. 2006. Removal of Seeds of Carapa procera (Meliaceae) by Rodents and Their Fate in Rainforest in French Guiana. J. Trop. Ecol. 12(6):751-761.

GRAGSON, T.L. \& BLOUNT, B.G. 1999. Ethnoecology: knowledge, resources, and rights. University of Georgia Press, Georgia.

HARRIES, H.C. 1979. The evolution, dissemination and classification of Cocos nucifera 1. New York Botanical Garden, New York.

HECHT, S.B. \& POSEY, D.A. 1989. Preliminary results on soil management techniques of the Kayapó Indians. In Resource management in Amazonia: indigenous and folk strategies (D.A. Posey \& W. Baleé, eds). New York Botanical Garden, New York, p. 174-188. (Advances in Economic Botany n. 7)

HOWE, H. 1982. Ecology of seed dispersal. Ann. Rev. Ecol. Syst. 13(1):201-228.

HOWE, J. 2002. The Kuna gathering: contemporary village politics in Panama. 2 ed. Fenestra Books, Tucson. (Latin American Monograph Series n. 67)

JORGE, M.L.S.P. 2007. Scatter-hoarding behavior of two Amazonian rodents: theory and application in forest fragments. Tese de Doutorado, University of Illinois, Chicago.

KELLERT, S.R. 1997. The value of life: biological diversity and human society. Island Press, Washington.
LÉA, V. 1992. Mebengokre (Kayapó) Onomastics: a facet of houses as total social facts in Central Brazil. Man 27(1):129-153.

LÉA, V. 1994. Gênero feminino Mebengokre (Kayapó): desvelando representações desgastadas. Cad. Pagu (3):85-116.

MARTIN, P.S. 1973. The discovery of America. Science 179(4077):969974.

MILLS, E.L., LEACH, J.H. CARLTON, J.T. \& SECOR, C.L. 1993. Exotic species in the Great Lakes: a history of biotic crises and anthropogenic introductions. J. Great Lakes Res. 19(1):1-54.

MORSELLO, C. 2002. Market integration and sustainability in Amazonian Indigenous Livelihoods: the case of the Kayapó. Tese de Doutorado, University of East Anglia, Norwich.

MYERS, J.H., SIMBERLOFF, D., KURIS, A.M. \& CAREY, J.R. 2000. Eradication revisited: dealing with exotic species. Trends Ecol. Evol. 15(8):316-320.

NASCIMENTO, H. 1999. Hunting sustainability by the Kayapó Indians of A-Ukre, eastern Brazilian Amazonia. Dissertação de Mestrado, University of East Anglia, Norwich.

OKWU, D.E. 2001. Improving the Nutritive Value of Cassava Tapioca Meal with Local Spices. J. Nutraceut. Function. Med. Foods 3(4):43-50.

PERES, C.A. \& ZIMMERMAN, B. 2001. Perils in Parks or Parks in Peril? Reconciling Conservation in Amazonian Reserves with and without Use. Conserv. Biol. 15(3):793-797.

PERES, C.A. 2000. Effects of subsistence hunting on vertebrate community structure in Amazonian Forests. Conserv. Biol. 14(1):240-253.

PEZZOPANE, J.R.M., GALLO, P.B., JÚNIOR, M.J.P. \& ORTOLANI, A.A. 2003 Microclimatic chacterization in coffee crop shaded by green dwarf coconut trees. Rev. Bras. Agrometeorologia 11(2):293-302.

POSEY, D.A. 1981. Wasps, Warriors and Fearless Men: ethnoentomology of the Kayapó Indians of Central Brazil. J. Ethnobiol. 1(1):165-174.

POSEY, D.A. 1983. Indigenous Ecological Knowledge: an ideological bridge to the future. Cienc. Cult. 35(7):877-894.

POSEY, D.A. 1985. Indigenous management of tropical forest ecosystems: the case of the Kayapó Indians of Brazilian Amazon. Agr. Syst. 3(2):139-158.

POSEY, D.A. 1989. Alternatives to forest destruction. The Ecol. 19(6):241-244.

POSEY, D.A. 1994. Environmental and social implications of pre- and postcontact situations on Brazilian Indians: the Kayapó and a new Amazonian synthesis. In Amazonian Indians from prehistory to the present: anthropological perspectives (A.C. Roosevelt, ed.). University of Arizona Press, Tucson, p. 271-286.

REDCLIFT, M. \& BENTON, T. 1994. Social theory and the global environment. Routledge, London.

REDFORD, K.H. \& STEARMAN, A.M. 1993. Biodiversity conservation and forest-dwelling native Amazonians: Agendas in common or agendas in collision. Cons. Biol. 7(2):248-255.

RIST, S. \& DAHDOUH-GUEBAS, F. 2006. Ethnosciences: a step towards the integration of scientific and indigenous forms of knowledge in the management of natural resources for the future. Env. Dev. Sust. 8(4):467-493.

SALM, R.A., FEDER, L., JARDIM, M.A.G., HASS, N., JALLES FILHO, E. \& COSTA, A.M. 2007. Conservation value of an exotic species: the case of coconuts on the Kayapó indigenous lands, south-eastern Amazonia. Env. Dev. Sust. 11(1):161-173.

SCHWARTZMAN, S., MOREIRA, D. \& NEPSTAD, D. 2000. Rethinking Tropical Forest Conservation: Perils in Parks. Conserv. Biol. 14(5):1351-1357.

SEOW, C.C. \& GWEE, C.N. 1997. Coconut milk: chemistry and technology. Int. J. Food Sci. Tech. 32(3):189-201.

SMYTHE, N. 1978. The natural history of the Central American agouti (Dasyprocta punctata). Smith. Contr. Zool. 257(1):1-52.

TURNER, T. 1992. Os Mebengokre Kayapó: história e mudança social, de comunidades autônomas para a coexistência. In História dos índios no Brasil (M.C. Cunha, ed.). Companhia das Letras, São Paulo, p. 311-338. 
TURNER, T. 1995. social body and embodied subject: bodiliness, subjectivity, and sociality among Kayapó. Cult. Anthropol. 10(2):143-170.

UNRUH, J.D. 1994. The role of land use pattern and process in the diffusion of valuable tree species. J. Biogeog. 21(3):283-295.

VERSWIJVER, G. 1992. The Club-fighters of the Amazon: warfare among the Kayapó Indians of Central Brazil. Rijksuniversiteit, Gent.

VIDAL, L. 1977. Morte e vida de uma sociedade indígena brasileira. Editora Hucitec, São Paulo.

WEINER, A.B. 1985. Inalienable wealth. Am. Ethnol. 12(2):210-227.

WESTOBY, M., LEISHMAN, M.R. \& LORD, J.M. 1996. Comparative ecology of seed size and dispersal. Phil. Trans. R. Soc. B. 351(1345):1309-1318.
ZANOTTI, L. \& CHERNELA, J. 2008. Conflicting Cultures of Nature: Ecotourism, Education and the Kayapó of Brazilian Amazon. Tourism Geogr. 10(4):495-521.

ZIMMERMAN, B., PERES, C.A., MALCOLM, J.R., \& TURNER, T. 2001. Conservation and development alliances with the Kayapó of Southeastern Amazonia, a tropical forest indigenous people. Environ. Conserv. 28(1):10-22.

Received 29/07/09 Revised 02/03/10 Accepted 03/03/10 